\title{
Perancangan Board Game sebagai Media Pembelajaran Keselamatan Berkendara untuk Remaja dengan Mekanik Dice Rolling
}

\author{
Peter Elianta ${ }^{*}$, Jasson Prestiliano ${ }^{2}$, T.Arie Setiawan ${ }^{3}$ \\ 1,2,3 Jurusan Desain Komunikasi Visual, Fakultas Teknologi Informasi Universitas Kristen Satya Wacana
}

\begin{tabular}{l} 
A R T I C L E I N F O \\
\hline Article history: \\
Received 19 May 2018 \\
Received in revised form \\
10 June 2018 \\
Accepted 28 July 2018 \\
Available online 25 August \\
2018 \\
\\
Kata Kunci: \\
Media Pembelajaran, \\
Keselamatan Berkendara, \\
Board Game \\
Keywords: \\
Keywords: \\
Learning Media, Safety \\
Riding, Board Game
\end{tabular}

\begin{abstract}
A B S T R A K
Keselamatan adalah hal yang penting dalam berkendara tak terkecuali mengendarai kendaraan pribadi. Kurangnya pemahaman tentang keselamatan berkendara dapat menyebabkan banyak pelanggaran bahkan kecelakaan di jalan raya. Polda Metro Jaya mencatat, pengemudi yang melanggar lalu lintas dari tahun 2016-2017 mengalami tren peningkatan. Pelaku pelanggaran yang paling mendominasi adalah pengendara motor berumur 17-30 tahun. Tujuan dari penelitian ini untuk merancang board game "Mudik Yuk" sebagai media dalam mempelajari keselamatan berkendara. Penelitian ini menggunakan metode deskriptif, strategi linear, dan pendekatan kombinasi. Data penelitian ini diperoleh dari wawancara, hasil penelitian , buku-buku, media berita online yang sudah ada tentang keselamatan berkendara dan pelanggarannya. Hasil dari penelitian ini adalah remaja menjadi lebih memahami tentang keselamatan berkendara setelah memainkan board game "Mudik Yuk".
\end{abstract}

\section{A B S T R A C T}

Safety is an important thing in driving, including driving a private vehicle. Lack of understanding about driving safety can cause many violations and even road accidents. Polda Metro Jaya noted, drivers who violate traffic from 2016-2017 experience an increasing trend. The most dominant violators were motorists aged 17-30 years. This study aims to design the "Mudik Yuk" board game as a media for learning safety riding. This study uses descriptive methods, linear strategies, and combination approaches. The data of this study were obtained from interviews, research results, books, existing online news media about driving safety and violations. The results of this study are that teenagers become more understanding about driving safety after playing the game board "Mudik Yuk".

\footnotetext{
* Corresponding author.

E-mail addresses: peterelianta23@gmail.com (Peter Elianta)
} 


\section{Pendahuluan}

Transportasi merupakan suatu kebutuhan yang sangat penting bagi masyarakat sekarang. Kebutuhan transportasi yang tinggi dapat dilihat dengan meningkatnya jumlah kendaraan bermotor yang ada sekarang. Jumlah sepeda motor di Indonesia telah menembus 100 juta unit pada 2016. Berdasarkan data Badan Pusat Statistik (BPS) jumlah kendaraan roda dua di tanah air telah mencapai 105,15 juta unit yang berarti meningkat 8,3 persen dari tahun sebelumnya baru sebanyak 98,88 juta unit. Jumlah sepeda motor mendominasi lebih dari 81 persen jumlah kendaraan bermotor nasional yang telah mencapai lebih dari 129 juta unit. Di urutan kedua adalah jenis mobil penumpang sebesar 11,27 persen (14,58 juta unit), kemudian diikuti mobil barang/truk sebesar 5,46 persen (7,06 juta unit), dan bis 1,92 persen $(2,49$ juta unit).

Dalam berkendara menggunakan kendaraan bermotor tidak lepas dari keselamatan diri. Keselamatan adalah hal yang penting dalam berkendara tak terkecuali mengendarai kendaraan pribadi. Keselamatan dalam berkendara dalam hal ini diarahkan pada upaya untuk menghindari terjadinya kecelakaan di jalanan (Fuller, 2005) dalam Haryanto (2016). Kurangnya paham tentang keselamatan berkendara dapat menyebabkan banyak pelanggaran bahkan kecelakaan di jalan raya. Berdasarkan data, pelaku pelanggaran dikelompokkan berdasarkan usia, pendidikan, pekerjaan dan jenis kendaraan. Dari data tersebut tercatat usia terbanyak adalah pengendara dengan rentang usia 31 hingga 40 tahun, yaitu 365.378 pelanggar. Posisi kedua ditempati oleh kelompok umur 16 sampai 30 tahun dengan 374.803 pelanggar. Sementara dari profesi, pegawai swasta yang terbanyak dalam data pelanggaran tahun 2016 dengan 635.495 pelanggar. Pelajar berada ditempat kedua dengan 52.868 pelanggaran ditahun 2016. Berdasarkan jenis kendaraan, pengendara roda dua melakukan pelanggaran terbanyak dengan 768.425 pelanggaran (Polda Metro Jaya, 2016).

Polda Metro Jaya mencatat, pengemudi yang melanggar lalu lintas dari tahun 2016-2017 mengalami tren peningkatan. Wakapolda Metro Jaya Brigjen Pol Purwadi memaparkan, Direktorat Lalu Lintas Polda Metro Jaya melakukan penindakan berupa tilang sebanyak 6.272.375 pada 2016. Pelanggaran lalu lintas mengalami kenaikan di tahun 2017. "Tahun 2017 sejumlah 7.420.000 kasus atau ada kenaikan tren 15,47 persen," ujar Purwadi di Polda Metro Jaya, Jakarta, Kamis (1/3/2018). Pihak Polda Metro Jaya juga memberikan klasifiksi jenis pelanggaran apa saja yang paling sering dilakukan oleh pengendara. Posisi pertama adalah pelanggaran marka sebanyak 16.902 kali, kemudian ada melawan arus dengan 12.487 kali pelanggaran dan kelengkapan surat-surat kendaraan sebanyak 11.234 kali.

Satlantas Polres Salatiga masih menjumpai ribuan pelanggaran yang dilakukan masyarakat pada Operasi Zebra Candi 2016. "Data yang kami himpun hingga Selasa (29/11/2016) pukul 24.00, jumlah pelanggaran dalam pelaksanaaan operasi selama 14 hari tersebut totalnya mencapai 3.210 pelanggaran," kata Kasatlantas Polres Salatiga AKP Edy Sutrisno kepada Tribun Jateng, Rabu (30/11/2016). Kasatlantas Polres Salatiga AKP Edy Sutrisna mengungkapkan selama menggelar Operasi Patuh Candi 2016 sudah lebih dari 585 pelanggar lalu lintas yang terjaring dalam razia. Di antara pelanggar itu, yang paling banyak terjaring adalah pelajar yang saat mengendarai kendaraannya tidak menggenakan helm. "Pelanggar ketertiban lalu lintas itu masih didominasi pelajar. Mereka acap kali menggendarai sepeda motor dengan tidak memakai helm, kelangkapan sepeda motor kurang maupun tidak memiliki SIM C".

Secara garis besar terdapat beberapa peraturan berkendara yang sebaiknya diketahui oleh para pengguna kendaraan bermotor, baik roda dua maupun roda empat atau lebih, antara lain memakai Helm Standar Nasional Indonesia (SNI), pastikan perlengkapan berkendara komplet, konsentrasi dalam berkendara, perhatikan pejalan kaki dan pesepeda, melengkapi kaca spion dan lain-lain, membawa STNK, SIM harus yang sah, wajib menyalakan lampu utama pada siang maupun malam hari, menggunakan lampu isyarat jika ingin belok, berbalik arah, menyesuaikan jalur dengan kecepatan.

Media pembelajaran adalah sarana fisik untuk menyampaikan isi/materi pembelajaran seperti : buku, film, video dan sebagainya, Briggs (1977), sedangkan menurut National Education Associaton (1969) mengungkapkan bahwa media pembelajaran adalah sarana komunikasi dalam bentuk cetak maupun pandang-dengar, termasuk teknologi perangkat keras. Dapat disimpulkan bahwa media pembelajaran adalah segala sesuatu yang dapat menyampaikan pesan, dapat merangsang fikiran, perasaan, dan kemauan peserta didik sehingga dapat mendorong terciptanya proses belajar pada diri peserta didik.

Pemahaman remaja mengenai keselamatan masih sedikit. Masih banyak pelanggaran yang terjadi. Bahkan banyak anak sekolah yang belum berumur 17 tahun membuat pelanggaran lalu lintas. Edukasi mengenai keselamatan berkendara dibutuhkan untuk menyadarkan pentingnya keselamatan berkendara untuk diri sendiri maupun orang lain. Simulasi dalam mengetahui dan belajar tentang keselamatan berkendara dapat menjadi sebuah jawaban untuk memberikan pengalaman pada remaja agar dapat merasakan keadaan dalam berkendara. 
Board game merupakan salah satu media yang dapat dijadikan simulasi berkendara dan mengalami keadaan berkendara di jalan raya serta mengerti edukasi tentang keselamatan berkendara. Dalam board game juga dapat menyuguhkan interaksi antar pemain sehingga remaja dapat bersimulasi memberikan teguran di jalan raya. Dalam Sejarah board game dan Psikologi Permainan, board game adalah jenis permainan di mana alat-alat atau bagian-bagian permainan ditempatkan, dipindahkan, atau digerakan pada permukaan yang telah ditandai atau dibagi-bagi menurut seperangkat aturan. Permainan mungkin didasarkan pada strategi murni, kesempatan, atau campuran dari keduanya dan biasanya memiliki tujuan yang harus dicapai (Mike Scorviano, 2010).

Game Mechanics atau mekanisme permainan dapat diartikan sebagai kerangka bagaimana cara permainan itu berjalan atau bisa dimainkan. Sebuah website yang berisikan database tentang board game dan card game yang pernah ada di dunia yaitu Board Game Geek (BGG) mengungkapkan ada lebih 75.000 judul board game dan card game. Database BGG mencatat ada 51 jenis mekanisme permainan, dice rolling merupakan mekanisme yang sudah tidak asing bagi pemain, sebagai contoh ular tangga dan monopoli. Permainan yang menggunakan mekanisme dice rolling tentu memerlukan dadu untuk dilempar. Hasil lemparan dadu bervariasi tergantung penggunaan dadu, bisa untuk langkah, menambah uang, atau mendapatkan sumber daya. Beberapa penelitian yang juga membahas tentang penggunaan board game dalam pembelajaran keselamatan berkendara sudah dilakukan sebelum penelitian ini.

Penelitian yang dilakukan oleh Ghaisa Manarina Nur Shabrina pada tahun 2014 yang berjudul Penggunaan Media Board game Dalam Pembelajaran Ketrampilan Berbicara Bahasa Perancis Pada Siswa Kelas IX SMA Plus Pariwisata Bandung Tahun Ajaran 2013/2014. Penelitian tersebut bertujuan untuk meningkatkan percaya diri siswa dalam menggunakan bahasa Perancis serta mengurangi kesulitan siswa dalam belajar berbicara bahasa Perancis. Penelitian lain dari Cecep Supriatna dan Sutono pada tahun 2016 yang berjudul Media Sosialisasi Rambu-Rambu Lalu Lintas Dengan Metode Augmented Reality Berbasis Android. Penelitian ini membuat masyarakat dan anak-anak bisa memahami arti rambu-rambu lalulintas, serta media sosialisasi ini efisien karena tidak memerlukan biaya yang besar. Penelitian lain dari Allez Martin Tangidy dan T. Arie Setiawan pada tahun 2016 yang berjudul Toleransi Melalui Model Budaya Pela Gandong Menggunakan Media Board Game untuk Mahasiswa. Penelitian ini dapat menyampaikan pesan-pesan yang terdapat pada budaya pela gandong pada mahasiswa melalui media board game.

Berdasarkan permasalahan yang ada dan diperkuat dengan tinjauan pustaka dengan menggunakan penelitian terdahulu, maka dirancang sebuah board game sebagai media pembelajaran untuk kalangan remaja mengenai keselamatan berkendara. Remaja dapat bermain sambil belajar sehingga diharapkan para remaja lebih paham dan dapat menerapkan tentang keselamatan berkendara..

\section{Metode}

Metode yang digunakan dalam penelitian ini adalah metode deskriptif dengan strategi linear. Metode deskriptif adalah suatu bentuk penelitian yang ditujukan untuk mendeskripsikan fenomenafenomena yang ada, baik fenomena alamiah maupun fenomena buatan manusia. Sukmadinata (2006:72). Strategi yang digunakan dalam penelitian ini adalah strategi linear. Strategi linear menetapkan urutan logis pada tahapan perancangan. Suatu tahap dapat dimulai setelah tahap sebelumnya diselesaikan (Sarwono, 2007). Tahapan penelitian dapat dilihat pada Gambar 1.

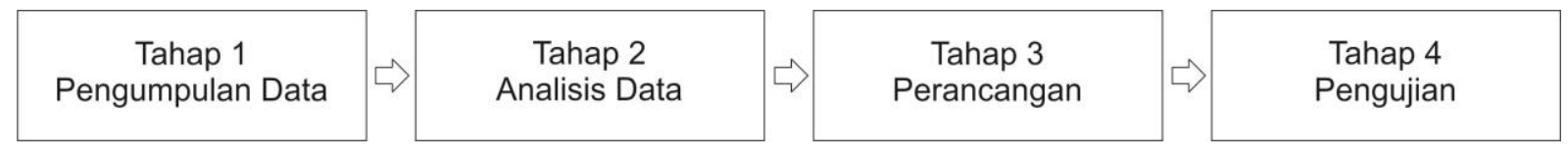

Gambar 1. Tahapan Penelitian

Tahap pertama merupakan pengumpulan data. Pada tahap pengumpulan data, dilakukan pengumpulan data secara kualitatif. Data primer pertama didapat dari wawancara dengan pihak kepolisian Salatiga. Wawancara dilakukan kepada Bp. Ibnu Awal Riyanto selaku Kaurbinops Satlantas Polres Salatiga. Data berikutnya diperoleh dari hasil wawancara kepada tujuh remaja yang berumur 17-21 tahun. Hasil penelitian dan media berita online yang merupakan data sekunder memperkuat data yang sudah ada. Tahap analisis data dilakukan berdasarkan data-data yang sudah terkumpul pada tahap sebelumnya agar dapat menentukan tindakan yang sesuai dengan masalah yang ada, agar media pembelajaran yang dibuat tidak jauh keluar atau melenceng dari konsep yang telah ditentukan. Pada tahap perancangan dilakukan perancangan board game untuk media pembelajaran keselamatan berkendara. Tahap perancangan ini berdasarkan konsep game design process oleh CEO Kummara, Eko 
Nugroho. Proses game design terdiri dari tiga fase utama, yaitu (1) concepting phase, (2) design phase, dan (3) production (development phase), proses tersebut dapat dilihat pada Gambar 2.

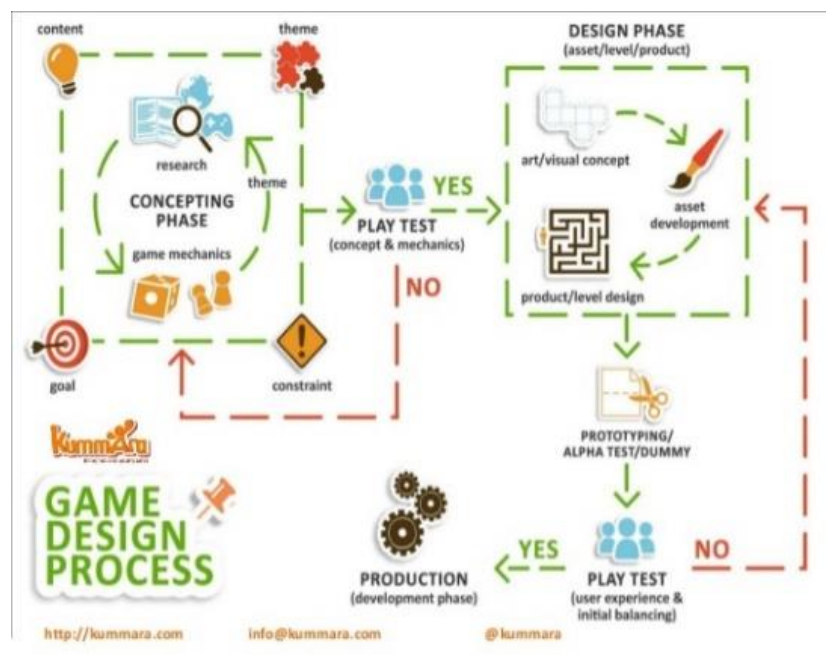

Gambar 2. Game Design Process

Dalam concepting phase, akan menentukkan elemen game berdasarkan analisis data yang sudah dilakukan sebelumnya, antara lain tujuan dari game, aturan dasar permainan, mekanisme permainan, serta cerita permainan. Dalam designphase dilakukan pembuatan prototype agar dapat mengetahui kekurangan dari cara bermain dan juga tampilan Board Game. Pembuatan hasil akhir Board Game yang sudah siap untuk diuji kepada target penelitian dilakukan dalam development phase.

Tahap pengujian dilakukan dengan pendekatan secara kualitatif dan kuantitatif. Pendekatan kualitatif dilakukan dengan mewawancarai pihak kepolisian dan mewawancarai para remaja yang sudah mendapatkan SIM dan biasa berkendara menggunakan kendaraan roda dua. Pendekatan kuantitatif dilakukan dengan membagikan kuesioner pada siswa Sekolah Menengah Atas untuk mengetahui efektif atau tidak penggunaan board game pada pemberian materi pembelajaran tentang keselamatan berkendara.

\section{Hasil dan pembahasan}

Dari hasil wawancara dengan pihak Satlantas Polres Salatiga Bapak Ibnu Awal Riyanto , Kepala Urusan Pembinaan Operasional (Kaurbinops) Satlantas Polres Salatiga, diperoleh data bahwa keselamatan berkendara / safety riding sangat penting agar tidak terjadi kecelakaan, baik diri sendiri maupun kecelakaan dengan orang lain. Sebelum berkendara, pengendara harus melakukan 3 SIAP yang meliputi siap diri, siap kendaraan dan siap mematuhi peraturan lalu lintas. Siap diri yaitu mempersiapkan diri baik jasmani maupun rohani sebelum berkendara dan saat berkendara. Siap kendaraan meliputi mempersiapkan kendaraan dalam keadaan baik sebelum berkendara agar tidak terjadi kecelakaan saat berkendara. Siap mematuhi peraturan lalu lintas meliputi mematuhi lampu lalu lintas serta rambu yang ada dan jangan mengebut ketika berkendara. Jika pengendara tidak mengutamakan safety riding, maka akan terjadi pelanggaran bahkan yang paling parah hingga terjadi kecelakaan. Pelanggaran yang sering terjadi adalah tidak memakai helm berstandar SNI, tidak memiliki atau tidak membawa SIM, spion yang tidak memenuhi standar (modifikasi). Pelanggaran dan kecelakaan yang sering terjadi dikarenakan pengendara ugal-ugalan dan ngebut dalam mengendarai serta tidak mematuhi peraturan lalu lintas, contohnya adalah tidak mematuhi lampu lalu lintas.

Berdasarkan wawancara kepada 7 orang remaja, semua sudah tahu tentang keselamatan berkendara namun 5 diantaranya belum mengetahui banyak tentang keselamatan berkendara dan sering tidak melakukannya sedangkan dua lainnya mengetahui dan sering melakukannya. Kurang tahu dikarenakan kurang adanya pembelajaran yang mengajarkan tentang pentingnya keselamatan berkendara dan hanya tahu dari orang tua yang mengajarkan cara berkendara dan tidak mengajarkan secara detail tentang keselamatan berkendara. Dari ketujuh remaja itu menyadari akan pentingnya keselamatan berkendara dalam melakukan kegiatan berkendara di jalan raya, baik untuk diri sendiri maupun untuk orang lain baik pengendara lain maupun pengguna jalan sekitar. 
Hasil dari pengumpulan data kemudian dianalisis dan dirancang sebuah konsep yang tepat dan sesuai dengan keperluan. Agar solusi dan tujuan perancangan dapat tersampaikan dengan baik dan tepat ke target penelitian, maka media pembelajaran yang dibuat tidak boleh lepas atau tidak sesuai dengan konsep yang telah dibuat.

Pada concepting phase, data-data yang telah dianalisis kemudian dijadikan materi yang akan disampaikan kepada target penelitian melalui media Board Game. Pembuatan konsep untuk menentukan apa yang ingin disampaikan melalui permainan ini, tujuan dari permainan ini, mekanik permainan, peraturan permainan, cerita permainan, serta komponen-komponen dalam permainan. Konsep yang dibuat adalah keselamatan berkendara yang baik dan benar di jalan raya yang berjarak jauh. Materi yang disampaikan berupa yang harus diperhatikan sebelum berkendara. Selain sebelum berkendara, materi tentang selama berkendara juga diberikan meliputi mematuhi rambu lalu lintas, memperhatikan keselamatan diri sendiri maupun orang lain.

Tujuan permainan ini adalah pulang menuju kota asal atau kampung halaman masing-masing dengan memperhatikan keselamatan berkendara dan persyaratan yang ada. Pemain dapat mempelajari keselamatan berkendara di jalan dengan adanya kartu event yang ada. Pemain yang sampai ke tujuan terlebih dahulu dan telah memenuhi persyaratan akan menjadi pemenangnya. Pemain akan lebih menikmati permainan ketika mendapatkan sebuah persaingan, interaksi dengan pemain lain, maka dari itu pada board game ini tantangan serta interaksi dimunculkan pada kartu event yang ada. Penggunaan dadu juga menambah tantangan bagi pemain dikarenakan pemain tidak tahu kapan akan mendapatkan angka besar maupun kecil.

Mekanisme permainan yang digunakan yaitu dengan kategori dice rolling dan tile placement. Penggunaan dice rolling membuat pemain tertantang karena mereka mengandalkan keberuntungan dalam mendapatkan angka dadu untuk menjalankan karakter yang ada di dalam permainan dan mengatur strategi untuk berjalan dari satu titik ke titik yang lain yang ada di tile jalan raya. Selain itu, mekanisme tile placement juga digunakan agar permainan menjadi lebih bervariasi dan tidak monoton. Pemasangan tile yang ada akan menciptakan suatu perjalanan baru dan tidak sama di setiap permainan yang dimainkan sehingga pemain dapat memperoleh pengalaman bermain yang berbeda.

Cerita dari permainan ini adalah empat orang yang merantau dan ingin pulang ke kampung halaman atau serring disebut dengan mudik. Sebelum perjalanan, mereka harus memperhatikan kelengkapan berkendara agar dapat selamat ke tujuan dan bertemu keluarga di rumah. Tidak lupa mereka membawa satu oleh-oleh dari kota rantau untuk keluarga di rumah. Kemudian, ditentukan judul untuk board game ini, adalah "Mudik Yuk" yang sesuai dengan cerita dan materi yang ada di dalam board game sehingga judul dapat menggambarkan cerita dan materi yang ada.

Pemain diharuskan memasang tile jalan raya agar dapat mengetahui jalan mana yang akan dilalui saat bermain sehingga pemain dapat menentukan jalan untuk ke tujuan yaitu kampung halaman masingmasing. Pemain diwajibkan memilih satu karakter untuk dapat memainkannya. Pemain juga diwajibkan memeriksa kelengkapan berkendara sebelum memulai perjalanannya dengan mengocok dadu. Pemain dapat berjalan di titik pada tile jalan raya dengan menggunakan dadu, dan berjalan sesuai angka dadu yang muncul. Di perjalanan setiap pemain akan mendapatkan beberapa kejadian yang tak terduga dan juga harus mematuhi rambu-rambu lalu lintas maupun lampu lalu lintas yang ada. Jika pemain ngebut, maka performa motor akan berkurang. Pemain yang sampai terlebih dahulu ke kampung halaman dengan membawa oleh-oleh maka dinyatakan sebagi pemenang. Mekanisme permainan dapat dilihat pada alur Gambar 3. 


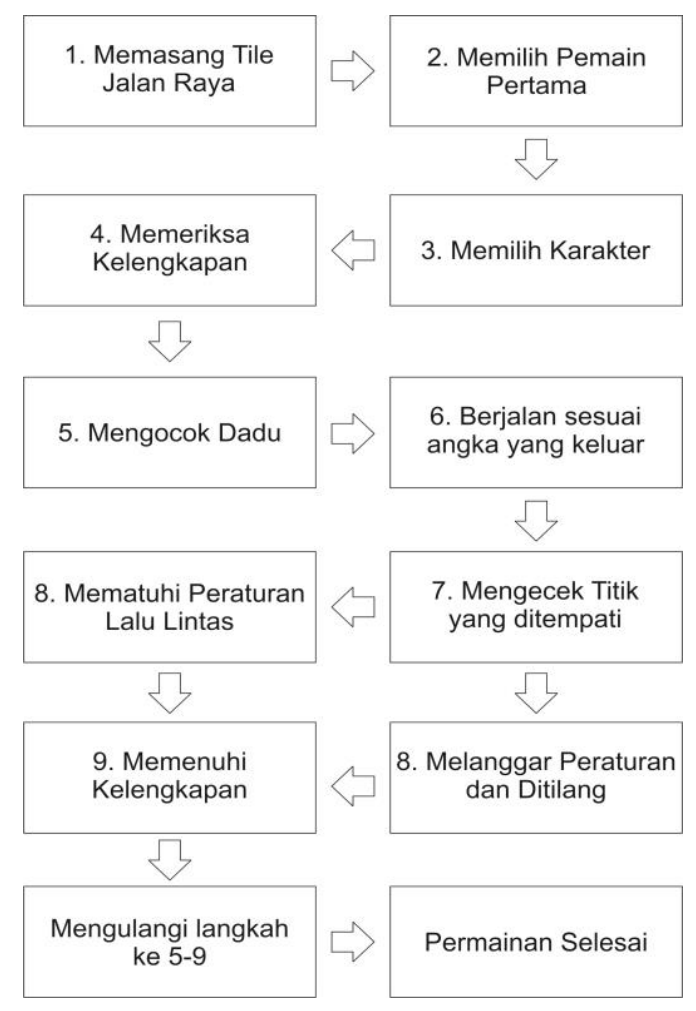

Gambar 3. Alur mekanisme permainan

Setelah konsep dasar sudah matang, maka akan dilakukan testplay. Testplay dilakukan dengan menggunakan prototype yang menggunakan bahan sederhana, yaitu dari kertas HVS yang dipotong dan diberi tulisan dan ilustrasi sederhana. Testplay dilakukan terus-menerus sampai permainan membuat para pemain merasa nyaman dan mudah dipahami. Dalam setiap testplay yang dilakukan, setiap saran akan dicatat untuk dijadikan sebagai evaluasi dan diuji lagi pada testplay berikutnya dengan menggunakan prototype yang sudah diperbaharui.

Pada Design Phase, konsep yang digunakan diolah dan dikembangkan lagi dan prototype sudah diberikan ilustrasi sederhana, seperti penggunaan teks, gambar, ikon, pengaturan tata letak tulisan serta gambar pada kartu dan tile. Pemberian ilustrasi berfungsi agar pemain dapat lebih memahami materi yang disampaikan pada kartu yang ada. Selain ilustrasi, warna juga diberikan agar pemain mudah membedakan kartu yang ada berdasarkan letaknya. Protoype kartu event Board Game Mudik Yuk dapat dilihat pada Gambar 4.
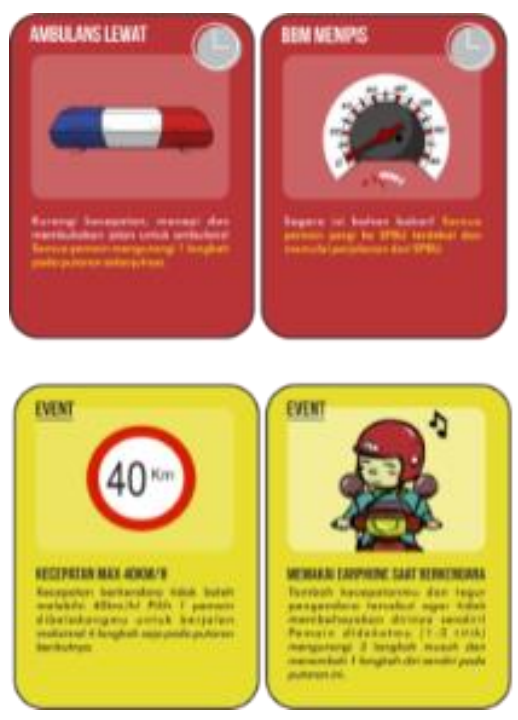

Gambar 4. Prototype kartu event 
Pemberian ilustrasi sederhana pada tile bertujuan agar pemain mengetahui letak token pengendara yang digunakan. Pada tile jalan raya juga terdapat lokasi tempat yang diperlukan untuk memenuhi persyaratan dalam permainan. Prototype tile jalan raya dapat dilihat pada Gambar 5.
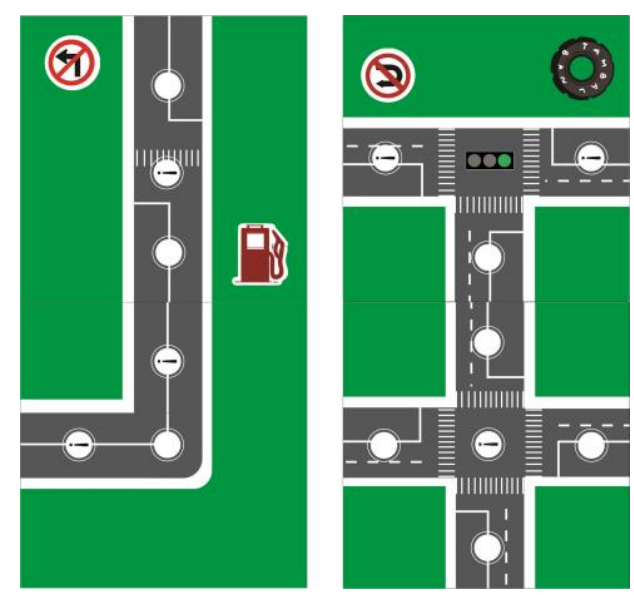

Gambar 5. Prototype tile jalan raya

Pembuatan prototype playerboard bertujuan untuk sebagai penanda keadaan komponen kendaraan yang dipakai dalam permainan dan dimiliki oleh setiap pemain. Playerboard dibuat menjadi 2 jenis yaitu memiliki atau tidak memiliki dan keadaan performa komponen kendaraan yang digunakan. Pada playerboard terdapat bagian yang dapat ditarik keluar masuk sehingga dapat memudahkan pemain mengubah angka performa maupun keadaan memiliki atau tidak. Ilustrasi yang digunakan di playerboard adalah persyaratan yang harus dilengkapi selama permainan berlangsung. Prototype playerboard dapat dilihat pada Gambar 6.

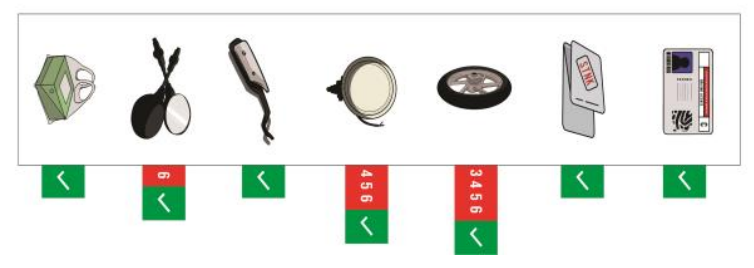

Gambar 6. Prototype playerboard

Selain playerboard, token pengendara akan dimiliki oleh tiap pemain sebagai penanda kendaraan yang akan mereka mainkan pada board game ini. Prototype dibuat dengan kertas yang diberi ilustrasi sederhana dan dibedakan warna setiap pemain agar mudah dibedakan. Prototype diberi penyangga kecil agar dapat berdiri dan dapat digerakkan saat bermain. Prototype token pemain dapat dilihat pada Gambar 7.

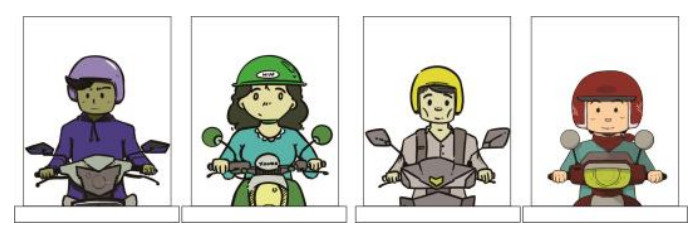

Gambar 7. Prototype token pengendara

Setelah itu, proses balancing dilakukan agar dapat membuat permainan menjadi seimbang, agar tidak terlalu mudah maupun terlalu sulit ketika dimainkan. Oleh karena itu, dadu dibagi menjadi dua jenis yaitu dadu performa dan dadu kecepatan. Dadu performa digunakan ketika pemain mendapat dadu kecepatan dengan angka diatas 4 dan berfungsi untuk mengurangi performa komponen yang ada pada motor yang digunakan. Dadu kecepatan digunakan untuk menjalankan pion kendaraan pemain. Jika 
pemain mendapatkan angka diatas 4 maka pemain dianggap ngebut. Prototype dadu performa dan dadu kecepatan dapat dilihat pada Gambar 8.

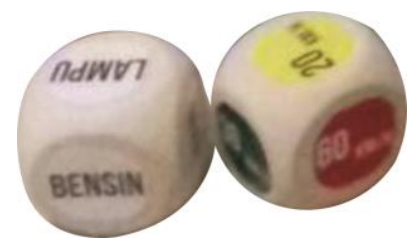

Gambar 8. Prototype dadu kecepatan dan performa

Selain dadu, koin juga dipakai sebagai komponen dalam board game ini. Koin digunakan sebagai penanda ada tidaknya polisi di jalan saat berkendara. Penggunaan koin dikarenakan koin hanya memiliki 2 sisi. Koin akan dilempar jika pemain melanggar rambu maupun lampu lalu lintas yang ada. Pada satu sisi terdapat logo polisi lalu lintas yang berarti ada polisi yang berjaga di lokasi pelanggaran terjadi, dan sisi lainnya terdapat logo polisi yang disilang yang menandakan bahwa tidak ada polisi yang berjaga. Prototype koin polisi dapat dilihat pada Gambar 9.

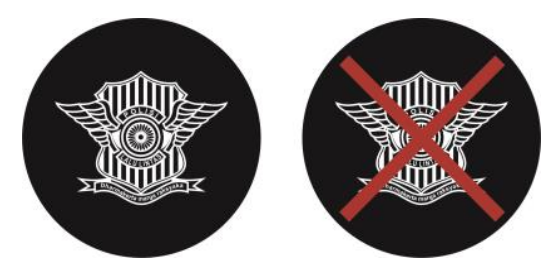

Gambar 9. Prototype koin polisi

Peletakan atau layout papan permainan diatur secara baik dan benar agar pemain tidak salah dalam meletakkan tile jalan raya. Tile dibagi menjadi 3 jenis berdasarkan zona yang telah ditentukan. Tiap zona yang ditentukan memiliki kelebihan dan kekurangan tersendiri sehingga harus sesuai dengan layout yang telah ditentukan. Selain tile, koin tilangan juga dibuat dan dimasukkan dalam layout. Layout prototype papan permainan dapat dilihat pada Gambar 10.

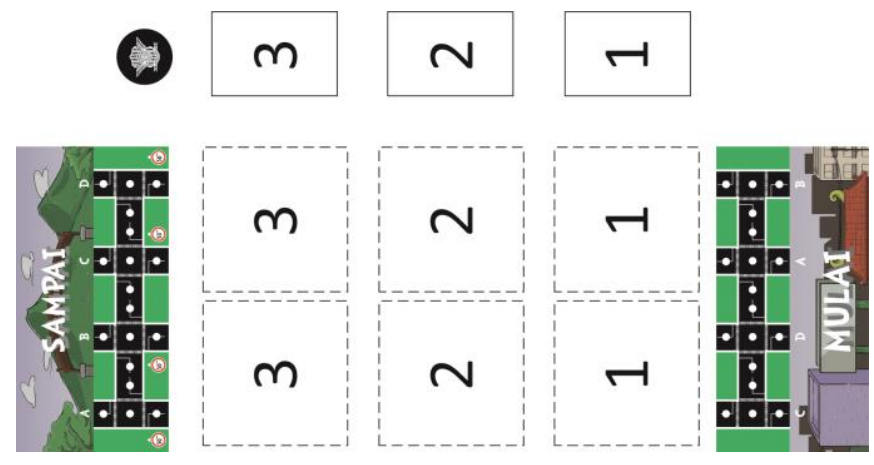

Gambar 10. Layout prototype papan permainan

Prototype ini kemudian dipakai untuk pengujian pertama kepada sampel target penelitian, yaitu remaja berusia 17 tahun keatas. Prototype yang dibuat akan di uji kembali ke target penelitian yaitu remaja untuk melihat apakah sudah baik ilustrasi, cara bermain, materi yang disampaikan, pengalaman dalam bermain secara keseluruhan sebelum nantinya menjadi hasil akhir. Maka nantinya, hasil akhir dari Board Game tidak akan lepas dari data-data testplay yang sudah dilakukan dan agar tujuan dari perancangan dapat tersampaikan dengan baik. Apabila prototype yang digunakan belum dapat membuahkan hasil yang maksimal maka fase ini akan diulang.

Pada Development Phase, prototype yang sudah baik akan disempurnakan dan dikembangkan kembali serta sesuai dengan hasil testplay. Jika prototype pada tahap sebelumnya dianggap belum cocok atau harus ada yang dikurangi, maka prototype tersebut akan diubah pada tahap ini. Pengembangan dapat dilakukan pada cara bermain, ilustrasi atau tata letak konten pada kartu. Penambahan komponen seperti koin lampu lalu lintas, kartu legenda dan buku panduan akan diberikan pada tahap ini. Koin lampu 
digunakan untuk mengetahui kondisi lampu lalu lintas yang ada. Kartu legenda digunakan untuk mempermudah pemain agar mengetahui simbol yang ada dalam tile. Buku panduan berisi tentang cara bermain, cerita, penjelasan peraturan secara detail , jumlah komponen yang tersedia serta nama designer dan illustrator board game Mudik Yuk. Buku panduan board game Mudik Yuk dapat dilihat pada Gambar 11.

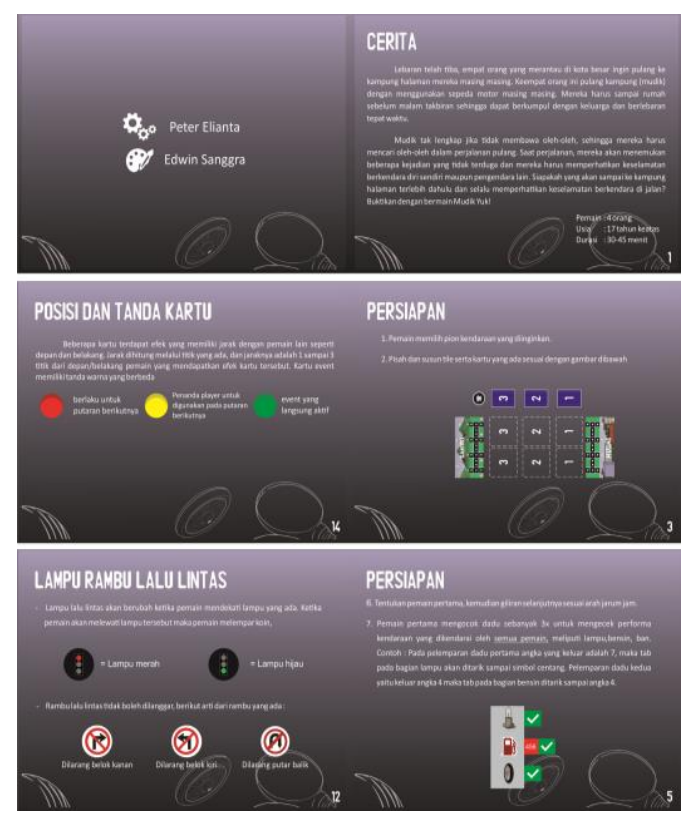

Gambar 11. Buku Panduan board game Mudik Yuk

Penggunaan warna pada kartu maupun ilustrasi yang ada disesuaikan dengan konsep, data yang ada serta saran yang diterima saat testplay. Selain pada kartu, token pengendara yang digunakan juga dibedakan warnanya agar mudah membedakan pemain satu dengan yang lainnya. Pada tahap ini, desain pada setiap komponen yang ada dalam board game Mudik Yuk telah selesai dan siap untuk diuji kepada target penelitian, yaitu remaja SMA yang berumur 17 tahun keatas. Komponen yang ada terdiri dari 1 buku panduan bermain, 1 deck kartu yang terdiri dari 30 kartu event, 6 tile jalan raya, 4 token pengendara, 4 playerboard, 2 buah dadu yang terdiri dari dadu performa dan dadu kecepatan, 2 koin yang terdiri dari koin lampu lalu lintas dan koin tilangan, dan 2 board. Hasil akhir board game ada pada fase ini.

Sebelum diuji kepada target yaitu remaja umur 17 tahun keatas, board game Mudik Yuk diuji terlebih dahulu kepada ahli desain board game Indonesia. Berdasarkan hasil wawancara terhadap Adhit WP, perancang board game The Art of Batik, didapatkan hasil bahwa board game Mudik Yuk sudah baik secara keseluruhan. Cara bermain board game Mudik Yuk mudah dipahami dan sesuai dengan targetnya yaitu remaja. Untuk sebuah simulasi berkendara di jalan, board game Mudik Yuk sudah cocok dan memberikan edukasi yang baik dan benar ketika sedang berkendara di jalan raya. Materi yang diberikan juga mudah dipahami. Komponen yang ada dianggap unik terutama di bagian playerboard karena dapat ditarik keluar dan ke dalam. Desain dan warna pada tiap komponen yang ada juga sudah menarik. Buku panduan cara bermain board game Mudik Yuk mudah untuk dipahami karena menggunakan bahasa yang sudah baik sehingga pemain tidak kebingungan membaca buku panduan ketika ingin memainkan boad game Mudik Yuk. Pengujian kepada ahli dapat dilihat pada Gambar 12.

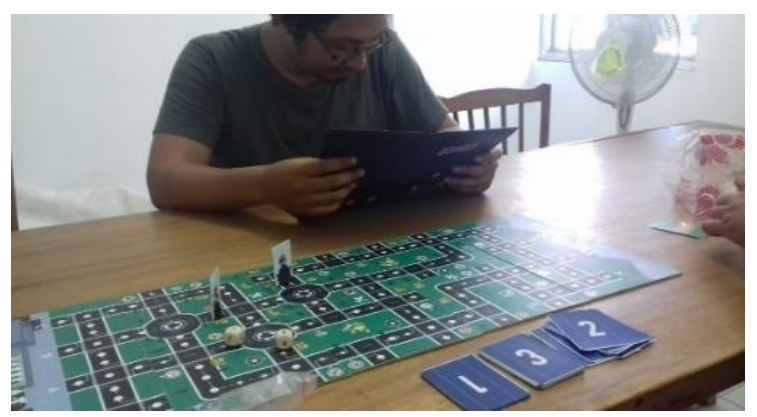

Gambar 12. Pengujian kepada ahli board game 
Board Game Mudik Yuk juga diujikan dengan tujuh orang anggota Komunitas Board Game Salatiga, yang merupakan komunitas di Salatiga yang aktif dalam hal mendesain dan memainkan referensi board game terutama board game edukasi. Dari hasil wawancara diperoleh hasil bahwa edukasi dalam board game sudah baik dan mudah dipahami baik dalam segi bermain maupun segi materi yang disampaikan. Selain itu, board game Mudik Yuk sudah sesuai dengan tujuan dan targetnya, yaitu untuk meningkatkan kesadaran keselamatan berkendara di jalan raya untuk remaja terutama yang berumur 17 tahun keatas.

Setelah diujikan kepada ahli dan komunitas, tahap pengujian dilakukan kepada remaja. Pengujian dilakukan melalui testplay terhadap 18 siswa kelas XII SMA Kristen 1 Salatiga. Pemilihan 18 siswa tersebut dikarenakan dari 30 siswa, terdapat 18 siswa yang sudah berkendara menggunakan motor dan berumur 17 tahun. Namun ada yang baru memiliki SIM dan ada juga yang belum memiliki SIM dan nekat berkendara motor di jalanan tanpa memperhatikan keselamatan orang lain. 18 siswa tersebut cocok untuk diberikan edukasi tentang keselamatan berkendara dikarenakan siswa tersebut dapat dibilang baru terjun ke dalam kegiatan berkendara di jalanan agar dapat mengerti bagaimana keselamatan berkendara itu diterapkan dan membuat dirinya maupun orang di sekitarnya selamat di jalan.

Pengujian ini bertujuan untuk mendapatkan data kuantitatif mengenai keberhasilan dari media pembelajaran yang dirancang, yaitu board game Mudik Yuk dari berbagai aspek, baik dari tampilan, cara bermain, pemahaman remaja dalam mempelajari keselamatan berkendara, serta efek yang ditimbulkan setelah memainkan board game Mudik Yuk. Pengujian dilakukan dalam dua sesi bermain, masing masing sesi berlangsung 30 menit untuk 8 siswa. Terdapat 2 siswa yang tidak dapat giliran bermain namun sangat antusias dengan board game Mudik Yuk dan menonton dari awal penjelasan sampai akhir permainan sehingga total siswa yang dipilih menjadi 18 orang. Pengujian kepada remaja dapat dilihat pada Gambar 13.

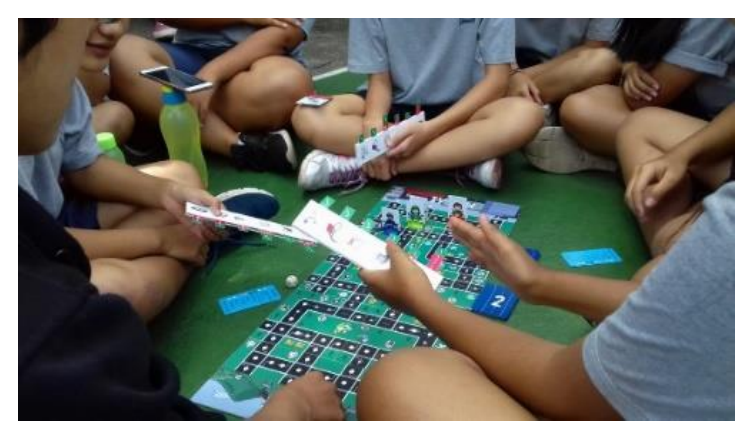

Gambar 13. Pengujian kepada remaja

Setelah selesai memainkan board game Mudik Yuk, dibagikan kuesioner dengan skala Likert kepada para siswa kelas XII SMA untuk mendapatkan data kuantitatif. Pernyataan tentang sikap seseorang terhadap sesuatu berhubungan dengan skala Likert, misalnya senang-tidak senang, setuju-tidak setuju, baik-tidak baik. Hasil pengujian kemudian diolah menggunakan perhitungan skala Likert untuk mengetahui persentase pendapat mahasiswa. Kuesioner yang dibagikan kepada remaja berisi pilihan jawaban dengan skala Sangat Setuju (SS), Setuju (S), Tidak Setuju (TS), dan Sangat Tidak Setuju (STS). Skala Likert adalah skala yang digunakan untuk mengukur sikap, pendapat dan persepsi seseorang, maupun kelompok mengenai sebuah peristiwa atau fenomena sosial, berdasarkan definisi operasional yang digunakan dalam penelitian (Ridwan, 2008).

Dari hasil pengujian kepada remaja didapatkan persentase sejumlah 93,3\% menyatakan sangat setuju melalui permainan ini, lebih dapat memahami tentang keselematan berkendara sehingga pentingnya keselamatan berkendara dapat tersampaikan dengan baik. Hasil pengujian juga menyatakan bahwa $87,7 \%$ responden sangat setuju ilustrasi dalam game menarik. $80,5 \%$ responden sangat setuju dengan penjelasan materi pada kartu mudah dipahami. 80,5\% responden sangat setuju dengan mekanik atau cara bermain dalam permainan ini tepat dan mudah dipahami.

Melalui hasil pengujian, board game Mudik Yuk berhasil menyampaikan beberapa pesan penting antara lain 1) Keselamatan berkendara berlaku untuk diri sendiri maupun orang lain ketika di jalan raya; 2) Mematuhi aturan, rambu rambu lalu lintas, serta lampu lalu lintas yang ada merupakan hal yang penting dan wajib dilakukan dalam berkendara di jalan; 3) Keselamatan berkendara tidak hanya ketika di jalan namun sebelum perjalanan harus memeriksa keadaan motor agar selamat ketika di jalan. Hasil akhir board game Mudik Yuk dapat dilihat pada Gambar 14. 


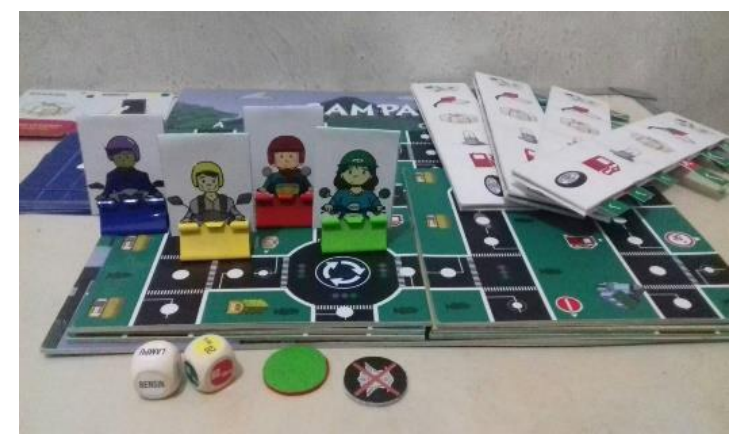

Gambar 14. Hasil Akhir Board Game Mudik Yuk

\section{Simpulan dan saran}

Keselamatan berkendara merupakan hal yang penting dalam berkendara. Namun, saat ini, kesadaran akan pentingnya keselamatan berkendara semakin menurun. Jika dibiarkan, akan terjadi banyak kecelakaan. Menyadarkan pentingnya keselamatan berkendara adalah dengan mengenalkannya kepada pengendara terutama pengendara baru. Walaupun sudah ada konsekuensi yaitu ditilang jika melanggar, namun kesadaran pengendara tetap kurang.

Board Game Mudik Yuk dapat menyampaikan pesan-pesan keselamatan berkendara pada remaja dengan bermain sambil belajar. Board Game Mudik Yuk dapat mensimulasikan berkendara dengan memperhatikan keselamatan berkendara ketika berada di jalanan dengan baik dan benar. Board game Mudik Yuk mendapat respon yang baik dari berbagai pihak sehingga sangat mungkin untuk dilakukan pengembangan.

\section{Daftar Rujukan}

Arsyad, A. (2011). Media Pembelajaran.Yogyakarta: Raja Grafindo.

Avianto,Yovita dan T Arie Setiawan. 2018. 'Pembelajaran Aksara Jawa Untuk Siswa Sekolah Dasar Dengan Menggunakan Media Boardgame’. Jurnal Aksara.30(1)133-148.

Belladino, Vicky. 2015. Mekanik 101: Dice Rolling, Lebih Dari Sekedar Melempar Dadu. http://boardgame.id/mekanik-101-dice-rolling-lebih-dari-sekedar-melempar-dadu/ (Diakses tanggal 14 Agustus 2017).

Destryawan, Dennis. 2018. Jumlah Pelanggar Lalu Lintas Tahun 2017 Meningkat 15,47 Persen. http://www.tribunnews.com/metropolitan/2018/03/01/jumlah-pelanggar-lalu-lintas-tahun2017-meningkat-1547-persen. (Diakses tanggal 5 Agustus 2018).

Muryatma, Nova Mega. 2017. 'Hubungan Antara Faktor Keselamatan Berkendara Dengan Perilaku Keselamatan Berkendara'. Jurnal Promosi dan Pendidikan. 5(2),155-166.

Nugroho, E. 2013. Game Design Process. http://www.slideshare.net/kummara/gamedesign-process2013-kummara (Diakses tanggal 14 Agustus 2017)

Saputro, D. A. 2016. Perancangan Media Edukasi Kandungan Berbahaya Junk Foodbagi Anak Sekolah Dasar denganMenggunakan Teknologi AugmentedReality Berbasis Android. Salatiga:Universitas Kristen Satya Wacana.

Setiawan, Deni, 2016. Pelanggar Lalu Lintas di Salatiga Didominasi Usia 21-25 Tahun. http://jateng.tribunnews.com/2016/11/30/pelanggar-lalu-lintas-di-salatiga-didominasi-usia-2125-tahun. (Diakses tanggal 14 Agustus 2017).

Saksono, Jessica Laurentia dan Deny Tri Ardianto. 2013. Perancangan Board game untuk Meningkatkan Kreativitas Menulis dan Menggambar Anak-Anak. http://studentjournal.petra.ac.id/index.php/dkv/article/view/625. (Diakses tanggal 10 Agustus 2017) 
Shabrina, Ghaisa Manarina Nur. 2014. Penggunaan Media Board game Dalam Pembelajaran Ketrampilan Berbicara Bahasa Perancis Pada Siswa Kelas IX SMA Plus Pariwisata Bandung Tahnun Ajaran 2013/2014. http://repository.upi.edu/6113/. (Diakses tanggal 10 Agustus 2017)

Supriatna Cecep dan Sutono Sutono. 2016. Media Sosialisasi Rambu-Rambu Lalu Lintas dengan Metode Augmented Reality Berbasis Android. Cianjur. Universitas Suryakancana.

Tangidy, Alez dan T Arie Setiawan. 2016.'Toleransi Melalui Model Budaya Pela Gandong Menggunakan Media Board Game untuk Mahasiswa'. Jurnal Kajian Kebudayaan. 11(2),16-25.

Undang-Undang Republik Indonesia Nomor 22 Tahun 2009 Tentang Lalu Lintas Dan Angkutan Jalan, Pasal 1 ayat 31-33. www.dpr.go.id/dokjdih/document/uu/UU_2009_22.pdf. (Diakses tanggal 10 Agustus 2017)

Vaganza. 2015. 51 Mekanik yang Kerap Digunakan dalam Tabeltop Game. http://boardgame.id/51gamemekanik-yang-kerap-digunakandalam-tabletop-game/ 